\title{
The Problem of Terrorism: Balancing risk between state and civil responsibilities
}

\author{
Melissa Bull \& Mark Craig*
}

\section{Introduction}

Contemporary society has been characterised as 'risk society' (Beck 1992). Beck believes that the processes of capitalist modernization have produced a series of unpredictable manufactured risks, and this signals a movement from a closely regulated industrial society to an unplanned risk society. Moreover, the localised risks identifiable in industrial society have given way to de-territorialised dangers of the risk society. Specifically with regard to terrorism Beck argues that its global reach demonstrates that 'national security is, in the borderless age of risk, no longer national security' (Beck 2002:14). This assessment seems plausible in the context of recent terrorist attacks, and is supported by dominant political narratives exemplified by British Prime Minister Blair's warning that 'we have got to be totally vigilant in the face of the threat because all major countries around the world face the same threat' (Waugh 2004:5). According to Beck the usual means for governing risk are inadequate in response to terrorism: insuring against terrorism is impossible, and the results of attack are potentially catastrophic. Beck claims traditional methods of calculating risk are limited in relation to protection against terrorism, but does this mean that risk is an ineffectual governmental principle in the face of this problem? This paper explores how approaches that employ the concept of risk somewhat differently allow us to engage with current responses to terrorism. In particular it draws on work from criminologists like David Garland and Pat O’Malley who have used the governmental formulations of risk to analyse the contemporary responses to crime.

In contrast to Beck, Garland (2001) and O’Malley (1992, 2001; see also Ericson \& Haggerty 1997, Stenson \& Sullivan 2000), working from the governmental perspective, highlight how neo-liberal states govern through the concept of risk. Through a range of assessment and profiling practices everything from spaces to populations are categorised according to a logic of risk which transforms danger into an objective (and potentially manageable) actuarial concept. According to Ewald (1991:207) risk works as a 'moral technology' regimenting and cajoling populations: it provides a way of organising time/ space and ordering the future. The objective here is to responsibilise individuals in relation to the risk and uncertainty of everyday life — be it financial security, employment, welfare

* Melissa Bull, PhD, School of Criminology and Criminal Justice, Griffith University, Brisbane, Q 4111, $<$ m.bull@griffith.edu.au>. Mark Craig, PhD, School of Justice, Faculty of Law, Queensland University of Technology, Kelvin Grove, Q, 4059, <m.craig@qut.edu.au>. 
or crime (Dean 1997). Through these processes populations become self-policing, and government is performed through risk-based techniques that are more subtle than sovereign forms of power.

According to Garland (2001) high rates of crime have come to be seen as a normal aspect of everyday life. Increasingly agencies of government have recognised the limits of sovereign power in preventing crime. Consistently high rates of crime and the apparent inability of the traditional institutions of the criminal justice system to have any significant or lasting impact on crime caused a crisis of control. Moreover, this resulted in a considerable rethink of state-centred responses to crime. The criminal justice state was joined by civil partners who worked in new ways to respond to the problems of crime and disorder, and crime control became a governmental concern that extended well beyond the apparatuses of the bureaucratic state. The new initiatives expanded beyond deterrence through punishment (the exercise of sovereign will), and environmental or rehabilitative responses commonly associated with corrective ends, to include more actuarial strategies aimed at managing the problem within reasonable limits through the calculation and mitigation of risk. Of course this was not without its problems.

Recently we have witnessed an increase in acts of terrorism targeting populations from industrialised western countries, and arguably (with September 11, the Bali bombings and a growing list associated with the fallout from the war in Iraq) the demonstrated limits of sovereign power as a response to such acts. This paper explores how the recent developments in the fields of criminology and crime control described by Garland (2001) apply to terrorism as an example of a governmental crisis. It begins by highlighting the factors that have drawn our attention to the limits of the state-centred approaches or sovereign power with regard to security and the protection of the population, and argues that the distinctive social, economic and cultural arrangements of late modernity have contributed to a collective experience of insecurity in relation to terrorism. That is, as with crime, the risk of terrorism has been enhanced by our daily routines and practices. Moreover terrorism is in the process of becoming a background feature of our everyday lives. Current global responses to terrorism are compared to those Garland links to the control of more localised and mundane types of crime. We argue that even though there is much debate about whether acts of terror amount to criminal behaviour or acts of war, consideration of the substantive and legislatively defined nature of the acts that constitute crime and terrorism makes it possible to consider the governance of terrorism as crime. The paper concludes by considering the consequences and limits of such an approach.

\section{Understanding terrorism: the problem of definition}

It is often noted that terrorism is a hard concept to define (O’Neill 2002a; Hayward \& Morrison 2002): 'one person's terrorist is another's freedom fighter'. Farhang Rajaee (2002:38) explains that 'on the one hand it is a serious violation of domestic and international laws, and on the other it has direct links to social, political and historical grievances'. It is an act that is not easily categorised as simply criminal because it often has a political dimension. It has a link to some notion of the public good, is often carried out in support of some public cause, and is an expression of public protest where the politics of inclusion fails. It may not be considered political because the legitimate use of violence has its own set of rules, but it is political because it is usually the weapon of a dispossessed group that feels it is excluded from public life and has no other means at its disposal. It is not usually an individual act - in that there is generally an organisation which supports the act itself, as well as a community of sympathisers behind the act, who consider it to be a legitimate form of expression and a means of advancing a particular cause (Rajaee 2002; Baregu 2002). 
Reinforcing this view Guitierrez (2002) argues that terrorism cannot be simply regarded as 'sickness'. There is a rationale for this type of activity, it should make sense for the person who commits it. It has to have some form of rationale, because it is not an irrational act of compulsion. As Findlay (2005:120) explains 'terrorists make choices dependant on an extant and common morality'. In doing so they act according to a rationality and are aware of what they are doing, having convinced themselves that the end justifies the means. It is a conscious strategy adopted to pursue a set goal.

Others take a more legalistic approach, proposing that terrorism is a substitute for conventional or classic warfare (Gasser 2002). International humanitarian law deals with humanitarian problems arising in warfare in which the armed forces of one state clash with the armed forces of another. The 1977 protocols to the 1949 Geneva Conventions include rules for hostilities involving forces other than governmental armies. Thus, according to Gasser (2002) - despite some important caveats with regard to the definition of armed groups and types of activities in Article 1 of the second Additional Protocol to the 1949 Conventions - modern international humanitarian law prohibits terrorist acts. Gasser argues that these international rules draw a line between acceptable and unacceptable methods of warfare. To resort to illegal methods and means - which includes terrorism violates the legal order, so terrorism is a crime which can be prosecuted as such under domestic law or as a war crime. ${ }^{1}$

In contrast, other commentators (eg O’Neill 2002a) propose that a crucial element in the definition of terrorism is that it is not simply common crime or random violence that harms civilians. It is premeditated and has a political or religious purpose. As a result it is not sufficient to simply look at the act, and ignore the actor or the circumstances of the act. From this perspective while terrorist groups may engage in drug trafficking, organised crime, money laundering or smuggling, they are fundamentally different from organisations whose raison d'etre is to engage in these activities. It follows that in combating terrorist acts, it is important for the United Nations to maintain this distinction in its anti-terrorism initiatives (O’Neill 2002a).

But is it necessary to maintain this distinction? In an August 2001 report Gary Crooke and the ill-fated National Crime Authority (NCA) pointed to the 'convergence' between transnational criminal organisations (TCOs) and terrorist organisations in a commentary that predated 9/11 (NCA 2001). The document described how terrorists cooperated with, coopted the services of, or adopted the methods of TCOs in order to raise funds to support their activities. Shelley (2005:9) comes to a similar conclusion:

[t]ransnational crime and terrorism are increasingly linked as criminal groups provide financial and logistical support. They may also provide technical support and cover for [terrorist] activities (see also Shelley \& Picarelli 2002).

This raises an important question: why wouldn't the strategies designed to limit the activities of TCOs be effective means for responding to terrorist activity? Does it matter that terrorism consisting of the same acts is often driven by fundamentalisms? Do strategic preventative interventions differ depending on whether a plane is hijacked for profit/ransom or for the release of political prisoners? Can terrorism be more successfully governed through populations and geographical space than through the souls of the terrorists? 


\section{Governing crime, governing terror: the limits of the nation state}

As noted above Garland (2001) claims that the closing decades of the twentieth century saw a change in the way governments in western industrialised states think about crime (and criminals). Authorities retreated from a concern with deterrence and rehabilitation, to focus more on the management and containment of the problem at acceptable levels. Offender centred correctional programs now compete on the public agenda with strategies concerned with preventing the offence and preventing victimisation. These new ways of thinking about crime begin from the premise that crime is a normal commonplace aspect of modern society. It requires no special motivation or disposition, no pathology or abnormality, and is part of the routines of contemporary social and economic life (Clarke 1997).

Garland and Sparkes (2000) argue that this situation is linked to the changed social conditions of late modernity. Changes in the profile of urban and suburban life transformed crime and incivilities from being problems that mostly affected the poor, to a daily consideration of anyone who owned a car, used a subway, left their house unguarded during the day, or walked the city streets at night. With consistently high rates of reported crime, policing practises that prioritised 'serious' crime at the expense of minor offences and the apparent failure of the traditional instruments of the sovereign state - police and the prisons - evidence of criminal activity became more apparent in the routines of the middle classes. This combined with a daily diet of crime reporting and dramatisations in the media, served to enhance and sustain collective feelings of insecurity (Garland 2001).

It is arguable that since $9 / 11$ the risk of terrorism has, in a similar way, become a routine consideration in the collective consciousness of populations of the industrialised west terrorist activity has become an 'everyday' (that is, common) cause of anxiety. Before this event - with a few exceptions - terrorist activities were seen by the English speaking world (particularly Americans) to be largely confined to 'third world' or 'poorer' non English speaking states that were considered by core powers to be fairly peripheral in terms of global governance and economic matters (Gunaratna 2002). With September 11 the target of terrorist activity shifted to the US - the most powerful/richest nation state in the world (O'Neill 2002a). With the Bali bombings, the bombing of the Marriott and the Australian Embassy in Jakarta, the trains and buses in Madrid and London and the ongoing struggle in Iraq it appears that the target extended beyond America to her allies (Guanaratna 2002). Moreover, the might of the powerful has repeatedly been seen to be powerless against such attacks, that is, in the face of terrorism sovereign power has its limits.

From being a problem that most affected developing countries on the other side of the world, terrorism and national (in)security, have increasingly become a daily consideration for anyone who regularly flies in a plane, travels by train or bus, works or lives in high-rise buildings, holidays at popular resorts, stays in five star hotels, frequents popular night club/ restaurant districts, works for a transnational corporation or government department. And as with crime, the threat of terrorism is enhanced through the routines of late modernity agricultural products (eg fertiliser as a component of explosives), electronic communication and communication devices (as detonators), aeroplanes, duty free alcohol purchased in airports (as Molotov cocktails) and so on, all come to hold potential as weapons for mass destruction.

The threat of terrorism has become an everyday reality in the lives and 'backyards' of those who, in the past, viewed such attacks as events that might occur in potentially exotic/ adventure holiday destinations. Of course this sense of fear and the evident inability of the nation state to protect its citizens is constantly transmitted into the homes of the US and its allies through daily news reports (Hayward \& Morrison 2002), daily talkback and public 
forum discussions in the media. Note for example the daily inclusion of terrorism as a news or current affair item in the media — the ABC Online website has more than 10,500 items listed under the topic of terrorism. Popular crime time TV dramas like Law and Order and CSI have modified their story lines to include terrorist themes, while in the US a new TV genre has emerged with series like Sleeper Cell and DHS (Department of Home Security).

\section{Responding to terrorism}

Discussion of how to respond to or prevent terrorism might logically begin with consideration of the causes of terrorism (like pursuing the causes of crime). O'Neill (2002a) notes that the academic debate most often centres on the question of whether poverty and/ or underdevelopment 'cause' terrorism, or if terrorism is unrelated to economic factors. The literature is replete with reports of how poverty and underdevelopment create grievances that terrorist leaders exploit for their own end. These conditions provide a ready pool of recruits, funds and other forms of active and passive support. Poverty and underdevelopment often coincide with limited or non-existent governance (Gutierrez 2002). 'Black holes' like Afghanistan, Pakistan, Liberia, Sierra Leone, Chechnya and Columbia, for example, provide ideal conditions for local or trans-national terrorists to flourish. These host states have limited or no control over what happens in large parts of their territory. They exercise limited sovereignty, and local extremist groups flourish by exploiting the discontent fed by corruption, poverty and authoritarian rulers. Their justice systems cannot or will not enforce the law, their borders are porous and their banking systems incapable of the most basic financial oversight. Weapons, drugs, illicit diamonds or other contraband flow easily, providing for the free movement of recruits, weapons and funds that allow terrorist networks to operate.

The international system of growing global institutions, trade and technological capacities, can exacerbate real and perceived inequalities between and within states. Terrorists exploit these gaps, using modern communications and jet travel to spread their ideologies, raise funds, recruit and hide. While there may be a growth of democratic institutions at the national level in many parts of the world the deepening asymmetries at the international level fuel resentment (Gutierrez 2002).

From this perspective a key strategy to prevent terrorism would be allowing people full participation in the economic and political systems of their states or in the new globalised international system: a global recognition and enforcement of human rights. A conference addressing the role of the UN in prevention concluded that development programs should be designed to promote a broader definition of human security, emphasizing the right to development. UN programs should address more strategically citizen participation, government accountability and transparency, based on the assumption that the greater the stake that citizens have in their societies the less likely they will support terrorism (O'Neill 2002b). Other solutions mentioned included nation building or capacity building and empowerment (Gutierrez 2002; Gunaratna 2002).

Empowerment, capacity building, and participatory democracy are concepts associated with critical criminological perspectives. But as Garland (2001) and O’Malley (2000) note there has been a recent antipathy to solutions concerned to address inequalities. In the criminal justice state this has amounted to a shift away from penal welfarist approaches and a rejection of strategies that address structural inequalities. Emphasis has been placed more on penalty and prevention, and this characterises what Garland has come to call a 'culture of control'. He argues that in this environment two ways of responding to crime are dominant: ‘expressive punitivism' and ‘preventive partnership' (Garland 2001). 
Preventive partnerships are informed by the new criminologies of everyday life; for example, rational choice theory, routine activity theory, crime as opportunity, and situational crime prevention. These approaches have been adopted by pragmatic policy makers to reorient government action and develop new techniques for governing crime. They depict crime as normal behaviour and the offender as a rational actor, not so different from his or her victim. Many of the programs of practical action which flow from this perspective are addressed not to the state agencies such as the police, courts and prisons/ corrections, but beyond the state apparatus, to the organisations, institutions of civil society - community groups, neighbourhoods, business groups or consumers. This approach recognises that the state has a limited capacity for control and looks to the everyday-life world to bring about change.

The preventive projects that develop are different in the agents they intend to empower, and they are different in the targets that they address. The new programs of action are directed not so much at individual offenders but towards the conduct of potential victims, to vulnerable situations, and those routines of everyday life, which create criminal opportunities as an unintended by-product. It aims to modify everyday routines by limiting the supply of crime opportunities, shifting risks, redistributing costs, and creating disincentives (cf Clarke 1997). It aims to embed controls in the fabric of normal interaction, rather than suspend them from above in the form of sovereign command enforced by the police.

In stark contrast, expressive punitivism — linked to an insistence by politicians, in the face of failure, that the state can protect its citizens - asserts that what is needed is a more forceful state centred approach: harsher penalties, more police and more prisons. This approach relies on notions of essentialised difference that represents criminals as dangerous members of distinct racial and social groups which bear little resemblance to 'us'. It trades in images, archetypes and anxieties. Offenders are described as evil and wicked. They are suitable enemies, for whom we can have no sympathy and for whom there is no effective help. The only practical rational response to such types is to have them 'taken out of circulation'.

We argue that Garland's culture of control is as evident in responses to terrorism as it is in responses to more 'mundane' crimes.

\section{Expressive Punitivism}

After 9/11 US President Bush announced his resolve to end terror everywhere. He spoke often and vigorously, proclaiming forcefully 'you're either with us or against us'. ${ }^{2}$ Opting for a state of war narrative, Bush declared 'war on terror', and on the night of the September 11 attacks, in a speech to the nation, made it clear that the US would not make any distinction between the terrorists and those who harboured them. What followed involved the constitution of the coalition of the willing to fight against the so-called 'axis of evil'. In simple terms this bifurcation led to the adoption, first and foremost of military strategies to defeat terrorists. But the outcome is far from simple, and its efficacy is regularly contested by ongoing attacks.

The concept of the 'war on terror' has been used to promote military cooperation involving intelligence sharing, establishing common databases, exchanging personnel, conducting joint training operations, sharing experience and expertise, and facilitating

2 CNN (2001), 'You are either with us organist us', November 6, <http://archives.cnn.com/2001/US/11/06/ gen.attack.on.terror/>, accessed 27 November 2006. 
transfers of technologies and harmonising judicial systems (Gunaratna 2002), and to justify a shift from reactive to pre-emptive strikes against Iraq (Gunaratna 2002:34; Crenshaw 2002). In response to the events of September 11, a number of democratic states including Australia, the US and the United Kingdom — took action to prevent terrorist acts from being committed in their territory. Such measures involve:

- tightening of police surveillance, particularly for foreign residents;

- adopting more robust interrogation procedures, which, may amount to inhumane treatment or even to torture;

- curtailing the right of alleged terrorists to a fair trial by, for example, imposing limits on access to counsel and witnesses, and on the exercise of other rights of the defendant; and

- toughening the state's stance towards asylum-seekers, refugees, and migrants, by, among other things, ignoring the prohibition on the return of such persons against their will to a country where they fear for their lives (Gasser 2002:51).

In Australia the federal government explained the features of the new security environment by outlining a national framework for countering terrorism. It articulated how 'the threat is global and enduring ... and was inspired by an extreme and militant distortion of Islamic doctrine that opposes the values of the West and modernity' (Commonwealth of Australia 2004:ii). The federal government argued it had 'systematically reviewed the critical components of Australia's protection against terrorism ... and ... established a national strategic framework based on the principles of maximum preparedness, comprehensive prevention and effective response' (Commonwealth of Australia 2004:iii). Its counterterrorism policy aims to ensure that the federal government has:

- high-quality intelligence to prevent and disrupt attacks against Australians or Australian interests at home or abroad;

- optimal strategies and arrangements in place to protect Australia's people, infrastructure and interests against the activities of terrorists; and

- the means to minimise the impact of a terrorist incident, should one occur (Commonwealth of Australia 2004:iii).

This policy is administered by the National Counter-Terrorism Committee (NCTC), the national coordinating body for counter-terrorism in Australia established by an InterGovernmental Agreement on national counter-terrorism arrangements on 24 October 2002. The NCTC's role is to:

- provide strategic and policy advice to heads of government and relevant ministers;

- coordinate an effective nation-wide counter-terrorism capability;

- maintain effective arrangements for sharing relevant intelligence and information between all relevant agencies in all jurisdictions;

- provide advice in relation to the administration of the special fund; and

- maintain the National Counter-Terrorism Plan (NCTP) and associated documentation (Commonwealth of Australia undated).

A new National Security Division was also created in the Department of the Prime Minister and Cabinet to effectively manage a whole of government framework for responding to terrorist incidents. In preparation for such incidents an enhanced programme of multijurisdictional counter-terrorism exercises was developed. To facilitate operational 
requirements and bring terrorists to justice comprehensive terrorism laws were introduced and greater power provided to the Australian intelligence community to collect information. Key pieces of Australia's national security legislation include:

- Anti-Terrorism Act (No. 2) 2005.

- Anti-Terrorism Act 2004.

- Anti-Terrorism Act (No. 2) 2004.

- Anti-Terrorism Act (No. 3) 2004.

- Australian Security Intelligence Organisation Act 1979.

- Australian Security Intelligence Organisation Amendment Act 2004.

- Australian Security Intelligence Organisation Legislation Amendment Act 2003.

- Australian Security Intelligence Organisation Legislation Amendment (Terrorism) Act 2003.

- Australian Federal Police and Other Legislation Amendment Act 2004.

- Australian Protective Service Amendment Act 2003.

- Aviation Transport Security Act 2004.

- Aviation Transport Security (Consequential Amendments and Transitional Provisions) Act 2004.

- Border Security Legislation Amendment Act 2002.

- Crimes Act 1914.

- Crimes Amendment Act 2002.

- Crimes (Overseas) Act 1964.

- Criminal Code Amendment (Anti-Hoax and Other Measures) Act 2002.

- Criminal Code Amendment (Espionage and Related Matters) Act 2002.

- Criminal Code Amendment (Offences Against Australians) Act 2002.

- Criminal Code Amendment (Suppression of Terrorist Bombings) Act 2002.

- Criminal Code Amendment (Terrorism) Act 2003 (Constitutional Reference of Power).

- International Transfer of Prisoners Amendment Act 2004.

- Maritime Transport Security Act 2003.

- National Security Information (Criminal and Civil Proceedings) Act 2004.

- Security Legislation Amendment (Terrorism) Act 2002.

- Suppression of the Financing of Terrorism Act 2002.

- Telecommunications Interception Legislation Amendment Act 2002.

- Telecommunications (Interception) Amendment Act 2004.

- Telecommunications (Interception) Amendment (Stored Communications) Act 2004. 
- Surveillance Devices Act 2004.

- Crimes Amendment Act 2005.

- National Security Information Legislation Amendment Act 2005.

Post the London bombings (7/7/05) the Australian federal government considered tough new anti-terror legislation and security measures, amongst these were: compulsory identity cards, increasing video surveillance in public space, enhancing transport security and preventing terrorism advocacy. ${ }^{3}$ A terrorism summit was held in late September 2005 at a special meeting of the Council of Australian Governments (COAG) to discuss these matters (ABC Radio Australia 2005). In the face of much public criticism tougher legislation was pushed through the Australian Parliament in its last week of sitting for 2005 (AntiTerrorism Act (No 2) 2005 (Cth)). The new anti-terrorism measures have been publicly denounced as 'draconian'. 4 They provide for control orders over terrorist suspects for up to 12 months, allow suspects to be held in preventive detention for up to 14 days, ban organisations which incite terrorism, create offences for urging hostility towards various groups and controversially update sedition offences. New anti-money laundering laws have been introduced to prevent the flow of funds to terrorists.

For the period 2001-02 to 2007-08 the federal government committed \$872 million to strengthen Australia's intelligence capabilities. This has included the establishment of a:

dedicated multi-agency, round-the-clock National Threat Assessment Centre, which is being supported by an expansion of international linkages and greatly enhanced practical cooperation with counterparts, particularly in the Asia-Pacific region (Commonwealth of Australia 2004:ix).

The three intelligence agencies responsible for analysis - the Office of National Assessments (ONA), the Australian Security Intelligence Organisation (ASIO) and the Defence Intelligence Organisation (DIO) - have all redirected their attention to terrorism. Further, ASIO will by, 2006-07, have increased its personnel levels by 80 per cent since 11 September 2001(Commonwealth of Australia 2004:xi).

The capacity of law enforcement agencies has also been strengthened to contribute to the counter-terrorism effort. The key objectives in relation to law enforcement are to:

- strengthen relationships and cooperation between federal, state and territory police;

- consolidate and build on the ability of law enforcement agencies to undertake investigations into transnational crime and terrorist activity;

- ensure that Australia's legal framework supports the ability of law enforcement agencies to carry out their work in the most effective way; and

- increase the contribution of the Australian Federal Police (AFP) to international law enforcement efforts (Commonwealth of Australia 2004:25).

3 Julia Medew, (2005) 'ID Cards on table at terror summit', The Age, 5 August,. < http://www.theage.com.au/ news/national/id-cards-on-table-at-terror-summit/2005/08/05/1123125891748.html?oneclick=true>, accessed 14 December 2005

4 Peter Hartcher (2005) 'Drastic measures for Unclear Dangers’, Sydney Morning Herald, November 4, <http:/ /www.smh.com.au/news/opinion/drastic-measures-for-unclear-dangers/2005/11/03/1130823341879.html>, accessed 14 December 2005; Ian Munro \& Fergus Shiel (2005) Howard's Security Move Draconian, The Age, September 9, <http://www.theage.com.au/news/war-on-terror/howards-security-move-draconian/2005/ 09/08/1125772640547.html>, accessed 14 December 2005; International Commission of Jurists Australian Section (2005) ICJ Australia Opposes New Counter-Terrorism Laws, Position Paper, 7 October, <http:// www.icj-aust.org.au/?no=33>, accessed 14 December 2005. 
To this end the federal government has provided additional funding of $\$ 500$ million to the AFP to investigate terrorist offences. One of the major AFP initiatives is the formation of Joint Counter-Terrorism Teams (JCTTs), which are mobile strike teams based in every state and territory (Commonwealth of Australia 2004:25).

The responses of prominent western states described above, and detailed more specifically in the Australian context, exemplify Garland's paradigm of expressive punitivism. The US President's characterisation of the 'axis of evil' is an obvious expression of essentialised difference. References to Islamic fundamentalisms and Muslim militants have the effect of singling out distinct racial and social groups in terms of dangerous archetypes in a way that promotes social division and generates anxiety. The insistence on the ability of the sovereign state to protect its citizens is backed by the expansion of policing and surveillance activities along with the proliferation of supporting legislation. These measures work to enhance state powers in ways that challenge neoliberal conventions in relation to natural justice, human rights and privacy. The efficacy and legitimacy of such approaches are beyond the scope of this paper, and discussed elsewhere (Braithwaite 2005, Findlay 2005, Mythen \& Walklate 2005). Here, considering the evident limits of sovereign state responses to terrorism - that is the State's inability to prevent terrorist attacks - we are interested in exploring governmental techniques that extend beyond the state. We focus on recent developments in Queensland as a case study.

\section{Preventive Partnerships}

In the latter part of the twentieth century, because of the inability of public policing to respond to and stem the problem of property crime and insecurity, civil agents began to assess the economic benefits that would flow from private security initiatives. The commercial sector's reaction to the crime threat was the development of a repertoire of private security arrangements (Garland 2000). This saw the re-emergence of private policing; the development of segregated spatial enclosures; managerial routines that make security an integral part of the organization's functioning; the development of cost-benefit crime-control analyses; security audits; and the blocking of opportunities for crime. The potential cost benefit derived from the private responses to everyday property crimes in the commercial sector was a driving force behind the development of these types of situational crime prevention strategies which are now commonplace (Clarke 1997; Gilling 1997). The positive outcomes of this in terms of reduced crime, and hence reduced losses, were further supported by insurers who responded with lower premiums for those who introduced targethardening measures to prevent or reduce the risk of victimisation. It must be highlighted here that the risk of victimisation was palpable, and there were calculable gains to be derived from such private initiatives.

In Australia, terrorism has been defined as criminal activity (eg Queensland Government 2003:4). All levels of government have identified the need for critical infrastructure protection. The federal government has identified major sectors of the economy, such as banking and finance, transport, energy, health, food supply, information technology and communications, as critical infrastructure. It believes a 'terrorist strike against any element of these vital national systems could have serious consequences for our economy and potentially lead to significant loss of life' (Commonwealth of Australia 2004:x). The Council of Australian Governments (COAG) has endorsed the 23 recommendations of the National Counter-Terrorism Committee on protecting national critical infrastructure (COAG 2004). However, the Australian Government has accepted that it is incapable of providing absolute protection, and, has encouraged businesses to take on responsibility by 
having up-to-date security and business continuity plans in place. Accordingly, it has argued that through... 'support for a strong business-government partnership, the Australian Government is facilitating work on identifying and assessing Australia's infrastructure, developing risk mitigation plans and harnessing analytical and modelling tools to support the development of nationally integrated, protective strategies'(Commonwealth of Australia 2004:x).

In Queensland the state government provides 'information, advice and support to assist critical infrastructure owners/operators in their development, validation and audit of risk and security plans'(Queensland Government 2003:3). The private sector is viewed as a 'vital partner in these endeavours' (Queensland Government undated a). It is, therefore, the responsibility of the private sector to ensure the protection of critical infrastructure under their control, and the Queensland Government has stated as much in their guidelines (Queensland Government undated a).

The state's counter-terrorism strategy (Queensland Government 2005) is described as a whole of government approach and its policy and planning activities impact upon Queensland in a wide range of sectors including: tourism; energy including electrical power systems, gas, oil and fuel; natural resource management, such as water supply systems, transportation systems; information and communications; food supply systems; health services; government services and emergency services. The stated aims of the strategy are to:

- prevent terrorist attacks,

- reduce the vulnerability of the State to terrorist attacks, and

- minimise the impact of any potential terrorist incident (Queensland Government 2005:6).

The Queensland Government Counter-Terrorism Strategy highlights the value of cooperative partnerships across government and with industry, as well as the provision of information, guidance and assistance to industry throughout the state to improve security preparedness. One of the stated initiatives to strengthen counter-terrorism planning is outlined under strategic directions as:

Promot[ing] the implementation of security, on-site emergency and business recovery plans which consider counter-terrorism at sites where large masses gather such as theme parks, shopping centres, sporting venues, international hotels, fast food outlets, entertainment venues, tourism sites, universities and transport precincts (Queensland Government 2005:14).

The Counter-Terrorism Strategy is quite explicit in its initiatives pertaining to critical infrastructure, and states that its protection:

... requires the active participation of the owners and operators of infrastructure, regulators, professional bodies and industry associations, in cooperation with all levels of government, and the public. Security Planning and Coordination (SPC) and the Counter Terrorism Coordination Unit (CTCU) are working collaboratively with the owners and operators of infrastructure and liaising across all levels of government and the private sector to build on existing mechanisms to ensure relevant systems and procedures are in place for prevention (including security), preparedness, response and recovery (Queensland Government undated b, emphasis added).

Local government, with its close connections to the community and its interest in social and economic development, is a key stakeholder in this process. Council representatives have been drawn into participation in critical infrastructure and mass gatherings infrastructure 
projects and national counter-terrorism exercises. The state government provided financial assistance to the Local Government Association of Queensland for the development of Local Government Counter-Terrorism Risk Management Guidelines as a resource for all local councils across the State (Queensland Government undated c). A local government counter-terrorism risk management kit (Local Government Association and Queensland Government 2004:3) was designed as a practical guide to integrate counter-terrorism considerations into disaster management arrangements. It sets out a methodology to prevent, respond to and recover from acts of terrorism. It is based on the risk management process in the Australian Standard and New Zealand Standard 4360 (AS/NZS 4360:1999) and users are not expected to have counter-terrorism expertise to complete the process.

According to the president of the Local Government Association of Queensland (LGAQ):

Queensland councils were as prepared as they could be to play key roles in managing the consequences of any terrorist acts within their jurisdictions. ... Queenslanders can take comfort from the fact that their local governments have been provided the tools and the training to identify security and terrorism-related risks to their communities (Local Government Association Queensland 2005).

Whilst acknowledging that the assessment of security or terrorist-related risks is a new dimension in the planning activities of local governments, the LGAQ believe '... it really is just an extension of their existing disaster management planning processes, ... [and] local governments need to be on the front foot in this important area of public safety' (Local Government Association Queensland 2005, emphasis added).

In considering the strengths and limitations of such strategies we need to keep in mind the fact that in a competitive neoliberal environment, businesses have vested interests and commercial considerations. Civil responses to crime have been self-motivated and driven by potential profit. Civil responsiveness to terrorism is driven by state directives, and not backed up, as Beck (2002) suggests, by insurance incentive. Indeed insurers explicitly list terrorist attack as an exclusionary event. Risk calculations in the face of terrorism, if it is distinguished as particular category of politically motivated behaviour, are not as evident as they are in relation to the prevention of property crime. It is likely that it will not be financially feasible to carte blanche provide the level of security and preventative measures warranted. This concern is not imaginary. Local government counter-terrorism risk management guidelines highlight cost as an important consideration in developing risk mitigation plans (Local Government Association of Queensland \& Queensland Government 2004). This is problematic, because with the privatisation of much critical infrastructure, on the one hand, the state is shifting the responsibility of protecting non-state facilities to owner/operators, while on the other, the private sector makes commercial decisions, and is likely to be financially motivated to rationalise its approach to security.

Over the past twenty years corporate security has moved from a peripheral activity to centre stage. Nevertheless, based on risk assessment principles there is, in reality, very little the private sector can do, or would be willing to do, past the point of mitigation to prevent a strategic terrorist attack against a major structure in Australia. There are of course, strategies that could be employed, such as the adoption of integrated urban security measures (crime prevention through environmental design, safe design, emergency risk management, physical security, and sustainability) (Yates 2003:25) and designing-in security measures prior to construction in the built environment is possible. The introduction of such measures are, however, difficult in dense urban environments and may limit commercial realisation opportunities and the maximisation of space, which is an undesirable outcome for local government. 
Indeed, as noted above, a reading of national, state and local government guidelines reveals that unlike crime prevention - where the point is to prevent an event from actually occurring (Van Dijk \& De Ward 1991) - the current focus of counter-terrorism risk strategies is on managing and containing the fall-out. This contrasts with the vision of some early proposals for counter-measures. For example, Richard Bulter, the former UN Weapons inspector, at the Local Government Association of Queensland's annual conference in 2003, suggested 'that councils must stretch residents' rates even further to ensure their cities are protected'. He urged councils to think of ways to doing these things by integrating them into things they already do, '... [which] shouldn't mean any extra cost to ... do these practical things'. Butler offered the applied example of checking for potential terrorist threats during routine building inspections (Jones 2003:13).

In short, instead of thinking more about prevention, the focus of current governmental strategies seems to be on managing the impact after an event occurs. Strategies principally involve integrating the problem of terrorism into current disaster management plans, and as a result risk oriented responses to terrorism continue to be reactive rather than proactive. This tends to be confirmed by the LGAQ's stated position that their planning is in reality '... just an extension of their existing disaster management planning processes ...' (Local Government Association Queensland 2005). Other important policy gaps appear with respect to the private sector that not only controls the majority of critical infrastructure in the nominated sectors identified by federal and state governments, but controls much else that is not nominated.

A practical example illustrates some of the limits of such an approach. The Gold Coast, which at June 30, 2004 had a population of 469,214, is the sixth largest city in Australia. ${ }^{5}$ In 2003/04 it was host to a total of 9,878,000 visitors and the visitor population in the region each day equates to approximately 78,900. ${ }^{6}$ The heart of the Gold Coast is Surfers Paradise, the high-rise strip which accommodates the vast majority of international visitors. It is a major business centre, and has attracted extensive international investment and recognition. ${ }^{7}$ But it is densely populated with some of the tallest buildings in the world either under construction or on the drawing board. There are 86 buildings, with 21-50 floors in existence, and currently 17 skyscrapers are under construction in or around Surfers Paradise ranging from 21-78 floors. A further 13 ranging from 23-72 floors have been proposed. $^{8}$

Local infrastructure, such as traffic management, is poorly planned and community services such as health are under pressure. The Gold Coast Hospital has the busiest Accident and Emergency ward in Australia and is regularly on by-pass - meaning ambulances must be diverted elsewhere (Craig 2005). Police do not have the resources to do much more than keep up with their traditional reactive policing routine. Added to this:

the state's fire-fighters say the service is in crisis, burdened with staff cuts, spiralling numbers of part-time employees, a clamp on training and plummeting morale....A national analysis of fire-fighting showed Queensland continued to rank near the bottom in key performance categories (Thompson 2005).

5 Gold Coast City Council Facts and Figures, <http://www.goldcoast.qld.gov.au/t_std.asp?PID=255>, accessed 14 December 2005.

6 Tourism Profile Gold Coast Region 2004, Gold Coast City Council, <http://www.goldcoast.qld.gov.au/ attachment/Tourism/2004\%20Tourism\%20Profile.pdf>, accessed 14 December 2005.

7 Surfers Paradise, Gold Coast City Council, <http://www.goldcoast.qld.gov.au/t_std2.asp?pid=241>, accessed 14 December 2005.

8 SkyscraperPage.com, <http://www.skyscraperpage.com/cities/?cityID=712\&statusID=2>, accessed 14 December 2005. 
The state member of parliament representing Surfers Paradise has specifically nominated: acute traffic congestion; under-funding of the Gold Coast Hospital; lack of a police presence in non-coastal parts of the electorate and inadequate police numbers; state government under-funding of water, public transport and road infrastructure as current issues in the electorate (Liberal Party of Australia, Queensland Division undated).

Taking this into account it is difficult to draw comfort from existing policies with respect to the detection and prevention of a terrorist attack. In terms of a response the emergency infrastructure is already straining to cope with conventional law enforcement, fire rescue, and health services. Poor transport design and management have ensured traffic is continually congested in and out of Surfers Paradise. Within existing disaster management arrangements, the capabilities of agencies to adequately deal with a major terrorist attack must be doubted. In this case it seems questionable whether the guidelines describing the standard for risk management will suffice or whether the risk treatment options, which incorporate prevention, preparedness, response, and recovery, will do any more than provide an on-going level of public reassurance (Ewald 1991).

\section{Concluding remarks}

We have argued that Garland's (2001) culture of control is as relevant to responses to terrorism, as it is to the more mundane experience of crime. In support of this claim we cited examples of expressive punitivism in the resolve of politicians that the state can protect its citizens from terrorism, and that what is needed is a more forceful state-centred approach. The proponents of this approach - evident in both the US and Australian contexts - can be seen to represent terrorists as dangerous members of distinct racial and social groups who bear little resemblance to 'us'; as evil; as suitable enemies, for whom we can have no sympathy. The only practical rational response to their existence is to take them 'out of circulation' (by sending suspects to Guantanamo Bay or detaining them for long periods without charge). The divisive cultural effects of this politics of exclusion (Young 1999; Rose 2000) are exemplified in Scott Poynting et al's Bin Laden in the Suburbs (2004), which argues that in Australia we are witnessing the emergence of the 'Arab Other' as the pre-emininent 'folk devil' of our time. Recent beachside riots at Cronulla tend to give Poynting et al's claims, and our assessment, some resonance (see Davies \& Porter 2005).

The main focus of this article has been to examine what could be described as preventive partnerships in relation to the protection of Australia's critical infrastructure. In policy documents and guidelines from the federal to the local government level there is an explicit/ clear recognition of the limits of the state and the need to develop 'strong businessgovernment partnership'. The Queensland Government views the private sector as 'a vital partner' in the development, validation and audit of risk and security plans for critical infrastructure (2003:23). A key feature of the government-sponsored counter-terrorism strategies described in this article, is that they are addressed not simply to state agencies but beyond the state apparatus to organisations and institutions of civil society. Programs of action are not directed so much towards terrorist actors, but rather to the conduct of potential victims, vulnerable situations and those routines of everyday life which create terrorist opportunities as an unintended by-product.

There are, however, limits to how much everyday routines can be modified to reduce the supply of terrorist opportunities, to shift risks, redistribute costs and create disincentives. There are limits, not the least of which are economic, on the extent to which controls can be embedded in the fabric of normal interaction. These limits are expressed with regard to the capacity of civil agents, as there is a tendency to see prevention 'as just an extension of ... 
existing disaster management planning processes' (LGAQ 2005). Of course some civil agents controlling airports, shipping and transport infrastructure have gone further than this, and are employing luggage or freight scanning. Some are considering the adoption of biometric profiling - techniques not without their own problems and limitations (Correy 2005). But in general the focus seems to be on mitigation, and this approach - even with the revision of disaster management strategies in the wake of 9/11 - is (as we have seen in relation to New Orleans) not likely to be sufficient.

Returning to the claim by Guitierrez (2002) that terrorism cannot be simply regarded as 'sickness', there is a rationale for this type of activity. It should make sense for the person who commits it; it has to have some form of rationale, because it is not an irrational act of compulsion. Terrorists act rationally and are aware of what they are doing, having convinced themselves that the end justifies the means. It is a conscious strategy adopted to pursue a set goal. Can we begin to think about terrorism differently? Is it helpful to move beyond views founded on notions of essentialised difference - the idea that terrorist actors bear little resemblance to us, are evil or wicked, and consider them as rational actors not so different from their victims? We argue that this approach is a logical application of Garland's new criminologies. This might sound a shocking proposition. Not so long ago it would have been forcefully rejected in relation to criminal offenders, and today it is a routine policy response. Support for such a rethink could be found in the interviews with the families and neighbours of the young British suicide bombers, who described them as normal young men (BBC News 2005).

We acknowledge that our analysis is specifically focused on a particular style of crime prevention and that there are limits to the application of these types of responses in this context. What we are suggesting is that there could be greater scope for such approaches. In terms of prevention it probably doesn't matter if a plane is hijacked for profit or for political reasons - the techniques for averting such an event regardless of motive would be much the same. After all, this is why biometric profiling initially put in place to detect and prevent non-politically motivated suicide and more mundane types of crime in the London tube system could be deployed to identify the perpetrators of the July 2005 bombing (Correy 2005), and techniques used to prevent money laundering by organised crime have been extended to prevent the flow of illegally gained funds to terrorist organisations. Admittedly the efficacy of this latter strategy is limited when resources are derived from small donations of legitimately accumulated funds.

The reluctance of political interests to think about terrorism in terms of crime limits their imagination, and their ability to think about how else the problem might be governed and what could be done to respond. Clearly some policy makers, academics and criminologists have begun to think this way (Horwitz 2005, Tough 2005, Kaplan \& Kress 2005). Crime prevention strategies developed in relation to 'conventional' crimes are being applied to terrorism. ${ }^{9}$ This is a good start but, as critiques of the situational approach to more mundane types of crime argue, it is best combined with other crime prevention strategies developmental, community/social and policing. From a preventive partnership perspective much could be done beyond situational prevention, particularly regarding social processes of exclusion and inequality. This is what Braithwaite (2005) is suggesting when he promotes the benefits to be derived from enlargement or the expansion of democracy and containment through regulatory processes in relation to the control of terrorism. On this front Andrew Goldsmith (2005), in his commentary on Braithwaite's work, raises an

9 Ron Clarke and Graeme Newman (2006) for example, have recently published a book on situational prevention and terrorism. 
important consideration by noting the difficulty of engaging Muslim subjectivities that are ill-disposed towards western values, institutions, and practices. Consideration of seemingly intractable problems like global inequalities and cultural imperialism is beyond the scope of this paper, but we have no doubt that it should be the focus of future counter terrorism research. We are nonetheless mindful of Dershorwitz's (2003:25) observation that:

...the reality is that the 'root causes' of terrorism are as varied as human nature. Every single 'root cause' associated with terrorism has existed for centuries and the vast majority of groups with equivalent or more compelling causes - and with far greater poverty and disadvantage - have never resorted to terrorism.

\section{References}

ABC Radio Australia (2005) 'Australia PM announces terrorism summit', 5 August 2005, <http://www.abc.net.au/ra/news/stories/s1431442.htm>, accessed 30 August 2005.

Baregu, M (2002) 'September 11: Structural causes and behavioural consequences of international terrorism', Responding to Terrorism: What Role for the United Nations?, International Peace Academy, Chadbourne \& Parke, New York City, pp 40-44.

BBC News, (2005) 'Suicide bombers' “ordinary” lives', UK Edition, July 18 2005, <http:/ /news.bbc.co.uk/1/hi/uk/4678837.stm>, accessed 30 August 2005.

Beck, U (1992) Risk Society: Towards a New Modernity, Sage, London.

Beck, U (2002) 'The Silence of Words and Political Dynamics in the World Risk Society', Logos, vol 1, pp 1-18.

Braithewaite, J (2005) ‘Pre-empting Terrorism’, Current Issues in Criminal Justice, vol 17, no 1, pp 96-114.

Clarke, RV (1997) Situational Crime Prevention: Successful Case Studies, $2^{\text {nd }}$ Ed, Harrow and Heston Publishers, New York.

Clarke, RV \& Newman, G (2006) Outsmarting the Terrorists, Praeger Security International, Westport Conn.

Commonwealth of Australia (undated) National Security Australia, National CounterTerrorism Committee, <http://www.nationalsecurity.gov.au/agd/www/NationalSecurity Home.nsf/0/97ACF5F35B392277CA256E58000E3E9E?OpenDocument>, accessed 14 December 2005.

Commonwealth of Australia (2003) National Counter-terrorism Plan, National CounterTerrorism Committee, Canberra, June.

Commonwealth of Australia, (2004) Protecting Australia Against Terrorism, Department of Prime Minister and Cabinet, Barton, <http://www.pmc.gov.au/publications/ protecting_australia/docs/protecting Australia .pdf>, accessed 14 December 2005.

Correy, S (2005) 'What's the data?', Back Ground Briefing, ABC Radio National, 28 August 2005, <http://www.abc.net.au/rn/talks/bbing/stories/s1445120.htm>, accessed 4 January 2005.

Council of Australian Governments (2004) Council of Australian Governments' Meeting, 25 June 2004, Canberra, <http://www.coag.gov.au/meetings/250604/communique250604 .rtf $>$, accessed 14 December 2005. 
Craig, M (2005) 'Terror Australis’, Security Solutions, vol 37, pp 122-128.

Crenshaw, M (2002) 'The Global Phenomenon of Terrorism', Responding to Terrorism: What Role for the United Nations?, International Peace Academy, Chadbourne \& Parke, New York City, pp 27-31.

Davies, A \& Porter, J (2005) 'United Condemnation, divided over the causes', Sydney Morning Herald, 12 December 2005, <http://www.smh.com.au/news/national/united-incondemnation-divided-over-the-causes/2005/12/11/1134235951340.html\#>, accessed 4 January 2006.

Dean, M (1997) 'Sociology After Society’ in Owen, D (ed) Sociology After Postmodernism, Sage, London.

Dershorwitz, A (2003) Why Terrorism Works, Melbourne, Scribe Publications.

Ericson, R \& Haggerty, K (1997) Policing the Risk Society, University of Toronto Press, Toronto.

Ewald, F (1991) 'Insurance and Risk' in Burchell, G, Gordon, C \& Miller, P (eds) The Foucault Effects: Studies in Governmentality, Harvester Wheatsheaf, London, pp 197-210.

Findlay, M (2005) 'Some Brief Observations on the Significance of Deterrence in Braithwaite’s “Pre-empting Terrorism”', Current Issues in Criminal Justice, vol 17, no1, pp 120-121.

Garland, D \& Sparks, R (2000) 'Criminology, social theory and the challenge of our times', British Journal of Criminology, vol 40, no 2, pp 189-204.

Garland, D (2000) 'The culture of high crime societies', The British Journal of Criminology, vol 40, no 3, pp 347-376.

Garland, D (1997) 'Governmentality and the problem of crime: Foucault, criminology, sociology’, Theoretical Criminology, vol 1, no 2.

Garland, D (2001) The Culture of Control: Crime and Social Order in Contemporary Society, Oxford University Press, Oxford.

Gasser, H (2002) 'International Humanitarian Law, the Prohibition of Terrorist Acts and the Fight Against Terrorism', Responding to Terrorism: What Role for the United Nations?, International Peace Academy, Chadbourne \& Parke, New York City, pp 49-52.

Gilling, D (1997) Crime prevention: Theory, policy and politics, UCL Press Limited, London.

Cronin, AK (2002) 'Rethinking sovereignty: American strategy in the age of terrorism', Survival, vol 44, no 2, pp 119-139.

Goldsmith, A (2005) 'Pre-empting Terrorism - A Comment', Current Issues in Criminal Justice, vol 17, no 1, pp 115-119.

Gunaratna, R (2002) 'Terrorism in the South Before and After 9/11: An Overlooked Phenomenon', Responding to Terrorism: What Role for the United Nations?, International Peace Academy, Chadbourne \& Parke, New York City, pp 32-34.

Gutierrez, F (2002) ‘Terrorism and Inequality’, Responding to Terrorism: What Role for the United Nations?, International Peace Academy, Chadbourne \& Parke, New York City, pp 45-48. 
Hayward, K \& Morrison, W (2002) 'Locating "Ground Zero": caught between the narratives of crime and war' in Strawson, J (ed) Law After Ground Zero, Glasshouse Press, London, pp 139-157.

Horwitz, S (2005) 'Police Chiefs Group Bolsters Policy on Suicide Bombers', Washington Post, August 4 2005, <http://www.washingtonpost.com/wp-dyn/content/article/2005/08/ 03/AR2005080301867_pf.html>, accessed 5 January 2006.

Jones, A (2003) 'Councils in anti-terror frontline', The Gold Coast Bulletin, Wednesday September 3, p 13.

Kaplan, EH \& Kress, M (2005) 'Operational effectiveness of suicide-bomber-detector schemes: A best- case analysis', Proceedings of the National Academy of Sciences of the United States of America, vol 102, pp 10399-10404.

Liberal Party of Australia, Queensland Division (undated) <http://www.qld.liberal.org.au/ $>$, accessed 14 December 2005.

Local Government Association of Queensland and Queensland Government (2004) Local government counter-terrorism risk management kit, State of Queensland and Local government of Queensland, Brisbane.

Local Government Association of Queensland (2005) 'Kit has Councils prepared to manage Consequences of Terrorist Acts' News Release, Local Government Association of Queensland, 14 July 2005, <http://www.lgaq.asn.au/portal/dt?action=content\&provider= JSPTabContainer>, accessed 14 December 2005.

National Crime Authority [NCA] (2001) Organised Crime In Australia: NCA Commentary, August, 2001.

O’Neill, WG (2002a) 'Beyond the Slogans: How Can the UN Respond to Terrorism?', Responding to Terrorism: What Role for the United Nations?, International Peace Academy, Chadbourne \& Parke, New York City, pp 5-17.

O’Neill, WG (2002b) 'Conference Report', Responding to Terrorism: What Role for the United Nations?, International Peace Academy, Chadbourne \& Parke, New York City, pp 18-26.

O'Malley, P (2000) 'Criminology of catastrophe? Understanding criminal justice on the edge of the new millennium', Australian and New Zealand Journal of Criminology, vol 33, no 2.

O’Malley, P (1992) 'Risk, power and crime prevention', Economy and Society, vol 21, no 3, pp 252-275.

O’Malley, P (2001) 'Discontinuity, Government and Risk: A response to Rigakos and Hadden’, Theoretical Criminology, vol 5, pp 85-92.

Poynting, S, Noble, G, Tabar, P \& Collins, J (2004) Bin Laden in the Suburbs: Criminalising the Arab Other, Institute of Criminology, Sydney.

Queensland Government (2005) Queensland Government Counter-Terrorism Strategy 2005-2007, State of Queensland, Brisbane.

Queensland Government (2003) Securing Queensland's Critical Infrastructure: Guidelines for Owners/Operators, Department of the Premier and Cabinet, Brisbane. 
Queensland Government (undated a) Planning for a Safer Queensland, Department of Premier and Cabinet, <http://www.premiers.qld.gov.au/Security_planning/securityplan/ saferqld/>, accessed 14 December 2005.

Queensland Government (undated b) Initiatives undertaken by the Queensland Government since 11 September 2001, Critical Infrastructure Protection, <http://www.premiers.qld.gov. au/Security_planning/securityplan/Queensland_Government_Counter-Terrorism_Strategy _2005-2007/Current_Queensland_Government_commitments/initiatives/>, accessed 14 December 2005.

Queensland Government (undated c) Initiatives undertaken by the Queensland Government since 11 September 2001, Critical Infrastructure Protection, <http:// www.premiers.qld.gov.au/Security_planning/securityplan/Queensland_Government_ Counter-Terrorism_Strategy_2005-2007/Current_Queensland_Government_ commitments/>, accessed 14 December 2005.

Rajaee, F (2002) 'The Challenges of the Rage of Empowered Dispossessed: The Case of the Muslim World', Responding to Terrorism: What Role for the United Nations?, International Peace Academy, Chadbourne \& Parke, New York City, pp 35-39.

Rose, N (2000) 'Government and control' in Garland, D \& Sparks, R (eds) Criminology and Social Theory, Oxford University Press, Oxford, pp 183-208.

Shelley, L (2005) 'Unravelling the New Criminal Nexus', Georgetown Journal of International Affairs, vol 6, no 1, pp 5-14.

Shelley, L \& Picarelli, J (2002) 'Methods not motives: Implications of the Convergence of International organised Crime and Terrorism', Police Practice and Research: An International Journal, vol 3, no 4, pp 305-18.

Stenson, K \& Sullivan, RR (2000) Crime, Risk and Justice, the politics of crime control in liberal democracies, Willan, Cullompton.

Thompson, T (2005) 'Firefighters say service in meltdown', The Courier Mail, 18 July, 2005, <http://www.couriermail.news.com.au/common/story_page/0,5936,15961557\% 255E952,00.html>, accessed 14 December 2005.

Tough, P (2005) 'Preventing Suicide Bombing', The New York Times, <http:// www.nytimes.com/2005/12/11/magazine/11ideas_section3-8.html?ex=1136610000\& en=d50b6df6bd520835\&ei=5070>, accessed 5 January 2006.

Van Dijk, J \& De Ward, J (1991) 'A Two-Dimensional Typology of Crime Prevention Projects with a Bibliography’, Criminal Justice Abstracts, vol 23, no 3, pp 483-503.

Waugh, P (2004) 'Blair: Britain Must Never Be Afraid to fight Terrorists', The Independent, 13 March 2004.

Yates, A (2003) Engineering A Safer Australia: Security critical Infrastructure and the Build Environment, Institution of Engineers, Canberra.

Young, J (1999) The Exclusive Society: Social Exclusion, Crime and Difference in Late Modernity, Sage, London. 